Natural Hazards and Earth System Sciences (2003) 3: 81-93

(C) European Geosciences Union 2003

Natural Hazards and Earth System Sciences

\title{
Distributed modelling of shallow landslides triggered by intense rainfall
}

\author{
G. B. Crosta and P. Frattini \\ Dip. Scienze Geologiche e Geotecnologie, Università degli Studi di Milano-Bicocca, Italy
}

Received: 27 November 2001 - Accepted: 1 February 2002

\begin{abstract}
Hazard assessment of shallow landslides represents an important aspect of land management in mountainous areas. Among all the methods proposed in the literature, physically based methods are the only ones that explicitly includes the dynamic factors that control landslide triggering (rainfall pattern, land-use). For this reason, they allow forecasting both the temporal and the spatial distribution of shallow landslides. Physically based methods for shallow landslides are based on the coupling of the infinite slope stability analysis with hydrological models. Three different gridbased distributed hydrological models are presented in this paper: a steady state model, a transient "piston-flow" wetting front model, and a transient diffusive model. A comparative test of these models was performed to simulate landslide occurred during a rainfall event (27-28 June 1997) that triggered hundreds of shallow landslides within Lecco province (central Southern Alps, Italy). In order to test the potential for a completely distributed model for rainfall-triggered landslides, radar detected rainfall intensity has been used. A new procedure for quantitative evaluation of distributed model performance is presented and used in this paper. The diffusive model results in the best model for the simulation of shallow landslide triggering after a rainfall event like the one that we have analysed. Finally, radar data available for the June 1997 event permitted greatly improving the simulation. In particular, radar data allowed to explain the non-uniform distribution of landslides within the study area.
\end{abstract}

\section{Introduction}

The analysis and forecast of temporal and spatial distribution of shallow landslides represent meaningful aspects of land management in mountainous areas. Shallow landslides (soil slips) are characterised by small thickness $(0.3-2 \mathrm{~m})$ and small scar areas (Campbell, 1975; Moser and Hohensinn,

Correspondence to: G. B. Crosta

(giovannib.crosta@unimib.it)
1983; Ellen, 1988, Crosta, 1998). They are mainly triggered during intense rainfall events by the rapid growth of pore pressure (Sidle and Swanston, 1982) or by the loss of the component of apparent cohesion (Fredlund, 1987). As a result, a failure surface develops within the soil profile or at the contact with the underlying bedrock. Through a transformation that can be due to liquefaction and dilatancy (Ellen and Fleming, 1987) the slipped mass evolve in a debris flow, that propagates downward eroding transport channels and increasing the volume of moving mass (Ellen, 1988, Crosta, 1998; Wieczorek et al., 2000). Factors controlling the occurrence and distribution of shallow landslides can be divided into two categories (Wu and Sidle, 1995): the almost-static variables and the dynamic variables. The almost-static variables, like soil properties (thickness, permeability and mechanical characteristics), seepage in the bedrock and topography (elevation, slope, areas of convergence and divergence, etc.), contribute to the definition of the susceptibility of the slopes to failure and they define the spatial distribution of the landslides. The dynamic or transitory variables, like the degree of saturation of the soil and the cohesion due to the presence of the roots and/or to partial saturation, control the triggering of failures along susceptible slopes. Climatic and hydrological processes and human activities control dynamic variables, and they characterise the temporal pattern of landslides. Shallow landslides hazard assessment requires an evaluation both of the susceptibility of the territory to fail and of the probability of occurrence of the phenomena in time.

Many methods for landslide susceptibility assessment have been proposed, namely: empirical evaluation of susceptibility of slopes to instability on the basis of geomorphological evidences (Brundsen et al., 1975; Humbert, 1977; Kienholz et al., 1978); statistical analysis (bivariate or multivariate) of the factors presumably responsible for landsliding (Brabb et al., 1984; Carrara, 1983; Yin and Yan, 1988; Bonham-Carter, 1990); analysis of the probability of failure with stability models based on stochastic hydrological simulations (Hammond et al., 1992). All these methodologies can be considered valid in certain contexts for some applica- 


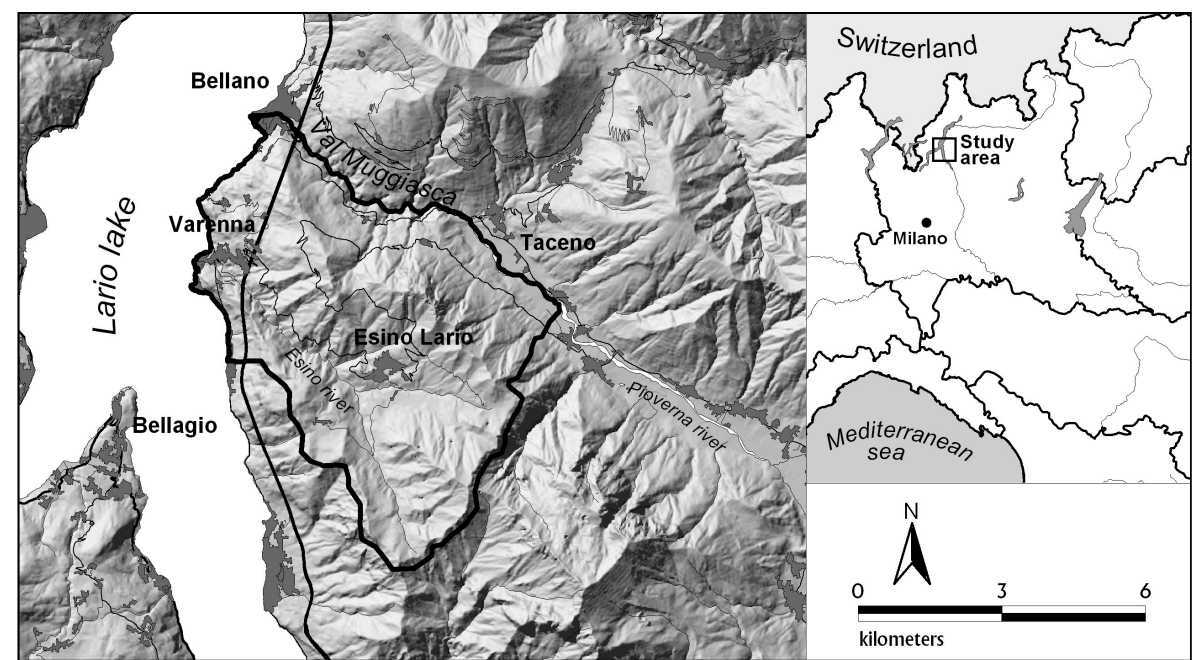

Fig. 1. Location map for the study area: Esino basin and left-hand flank of the Muggiasca Valley (northern Italy, Lombardy). The thick black line shows the extension of the study area $\left(38 \mathrm{~km}^{2}\right)$. tions. None of them, however, expressly takes into account the dynamic variables of the system as well as their shorttime and long-time behaviour. This variability is considered by physically based mathematical models that explicitly incorporate the dynamic variables. Different models have been developed to describe how landslide triggering depends on dynamic variables as hydrological conditions and land use changes (Montgomery and Dietrich, 1994; Wu and Sidle, 1995; Borga et al., 1998; Pack et al., 1998). These models are based on the coupling of the infinite slope stability analysis with hydrological models able to modulate water table heights in steady or quasi-steady conditions with groundwater flows parallel to the slope. The assumptions of these models are too restrictive under certain conditions. For example, pore water pressure in hillslopes responds very rapidly to transient rainfall, and the pressure redistribution includes a large component normal to slope. In order to overtake these limitations, Iverson (2000) has recently developed a flexible modelling framework, with different approximations of Richards (1931) equation valid for varying periods of time and for different hydrological conditions.

In this study we apply and compare different modelling strategies in an area of the Lecco province, Lombardy, that was impacted by many shallow landslides following an intense rainfall event (27-28 June 1997). In particular, in order to test the potential for a completely distributed model for rainfall-triggered landslide, radar detected rainfall intensity has been used (Crosta et al., 2001).

\section{Study area}

The study area is located on the eastern side of Lario lake (Lombardy Region, northern Italy) and includes the Esino river basin and the southern side of Muggiasca Valley (Fig. 1). This valley corresponds to the lower basin of the Pioverna river basin, from Taceno to Bellano, and adjoins the northern border of Esino basin. The whole study area has an extension of $38 \mathrm{~km}^{2}$ and is situated between $200 \mathrm{~m}$ and $1830 \mathrm{~m}$ a.s.l. The mean annual precipitation ranges from $1450 \mathrm{~mm}$ in the lower part of the basin, to $1650 \mathrm{~mm}$ in the upper part. The main portion of the study area is characterised by massive limestones (Esino Fm., Late Anisian to Ladinian, Fig. 2a), covered and mantled, in the gently sloping areas, with thick glacial deposits. The western part of the area is characterised by well bedded black micritic limestones with non oxidized carbonic matter and intercalations of very fine tuffitic layers (Perledo Varenna Fm., Ladinian). In the northern part of the area there is a rapid succession of different sedimentary units: well bedded light grey dolomites (Albiga dolostone, Late Anisian to Early Ladinian), thick bedded sandstones and fine conglomerates, with dolomitic intercalations (Bellano Fm., Early to Middle Anisian), quartzites and quartz fine conglomerates ("Servino" Fm., Scythian) and red and green conglomerates ("Verrucano Lombardo" Fm., Late Permian). These units lie in stratigraphical contact on the top of the basement (Schönborn, 1992) that is composed of gneiss and micaschists (Morbegno Gneiss).

Most of the area is covered by colluvial soils, with a depth ranging from 0.3 to $1.5 \mathrm{~m}$. A large portion of central Esino basin is covered by thick glacial deposits, up to $15 \mathrm{~m}$ in depth, whereas discontinuous scree slope deposits can be found under the main calcareous scarps (Fig. 2b). Finally, land use is primarily forest, with discontinuous meadows around Esino and few terraced areas on the lake side near Bellano (Fig. 2c). A map of the soil type and thickness has been prepared on the basis of field observations and laboratory data and through the overlay of different thematic maps (e.g. geology, surficial geology, land use, terrain slope).

\section{The 27-28 June 1997 event}

A short-duration high-intensity rainfall event impacted the basin of Esino river on 27-28 June 1997. In less than $2 \mathrm{~h}$ almost $100 \mathrm{~mm}$ of rain fell within the study area, triggering 

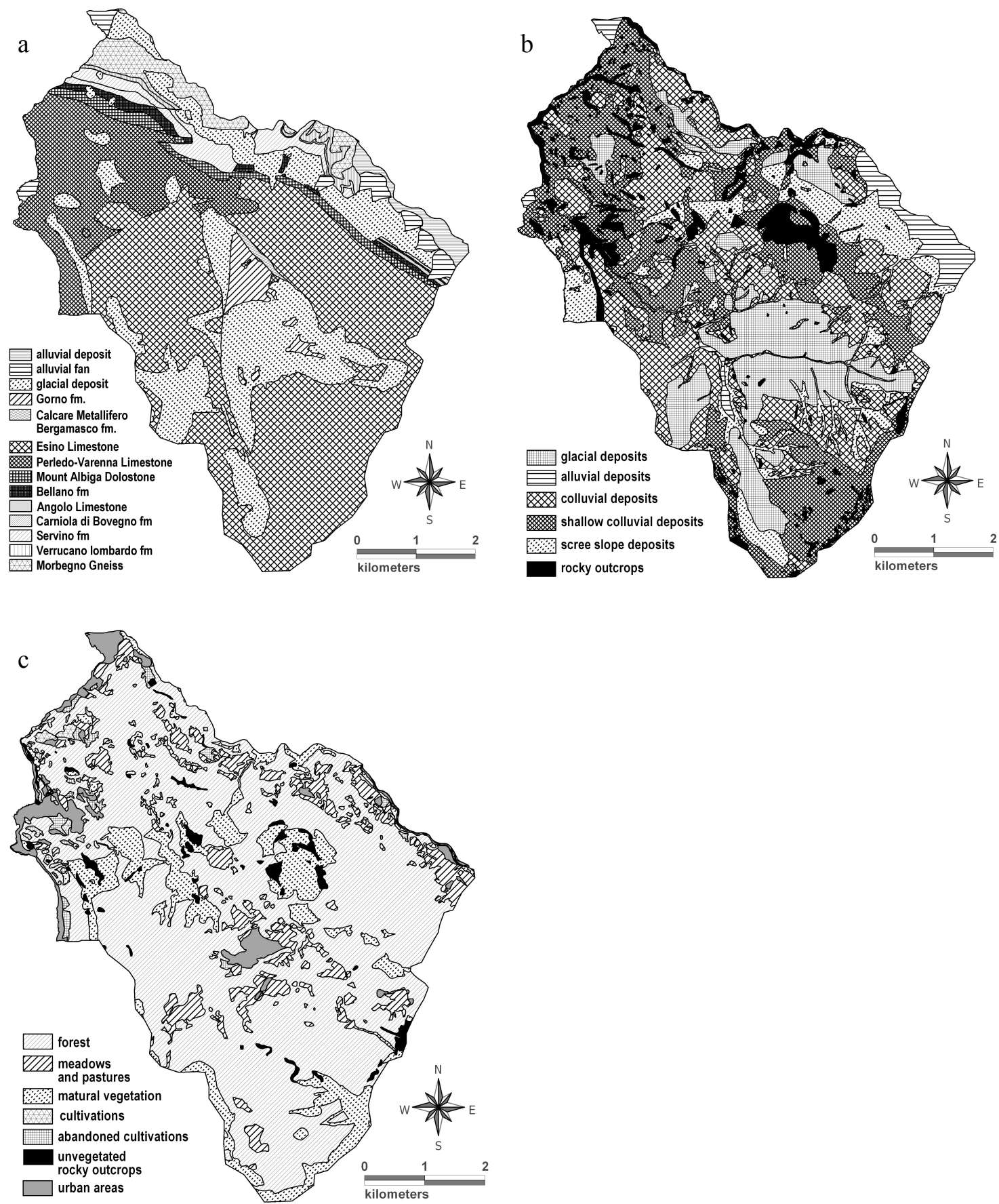

Fig. 2. Thematic maps for the study area: (a) geological map; (b) surficial geology map; (c) land-use map. Different physical, hydrological and mechanical properties have been attributed to each soil class of the surficial geology map.

many landslides. Rain gauge data and radar images have been used to describe the rainfall event. Rain gauges with hourly records are located in Bellano (202 $\mathrm{m}$ a.s.1.), on the north east edge of the study area and Barzio (755 m a.s.l.), $8 \mathrm{~km}$ to the east. Radar data from Mount Lema radar station, $35 \mathrm{~km}$ to the west of the study area, were provided by the Swiss Meteorological Institute.

Rainfall intensities $(R)$ are estimated from the measured radar reflectivity $(Z)$ with a $Z-R$ relationship, with 5 min time interval between measurements, and with a spatial resolution of $1 \times 1 \mathrm{~km}$. Differences between radar-based estimates of rainfalls and ground-based measurements arise from instrumental aspects - such as the stability of the radar hardware - from meteorological processes (raindrops size, wind direction, cloud structures) and from the orography. In order to correct those factors that affect the accuracy of the 

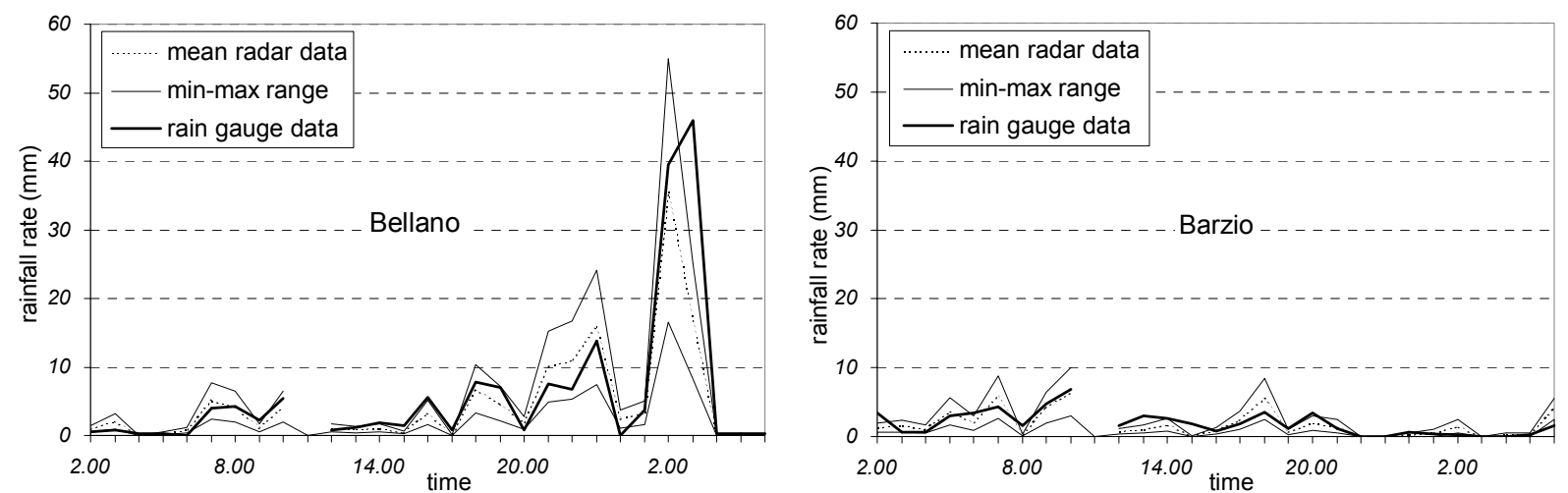

Fig. 3. Hourly rainfall data from 02:00 LT of 27 June to 06:00 LT of 28 June 1997 from Bellano and Barzio rain gauges. Radar data at 30 min time interval, from Mount Lema station (Swiss Meteorological Institute), have been hourly averaged for comparison with rain gauge data.
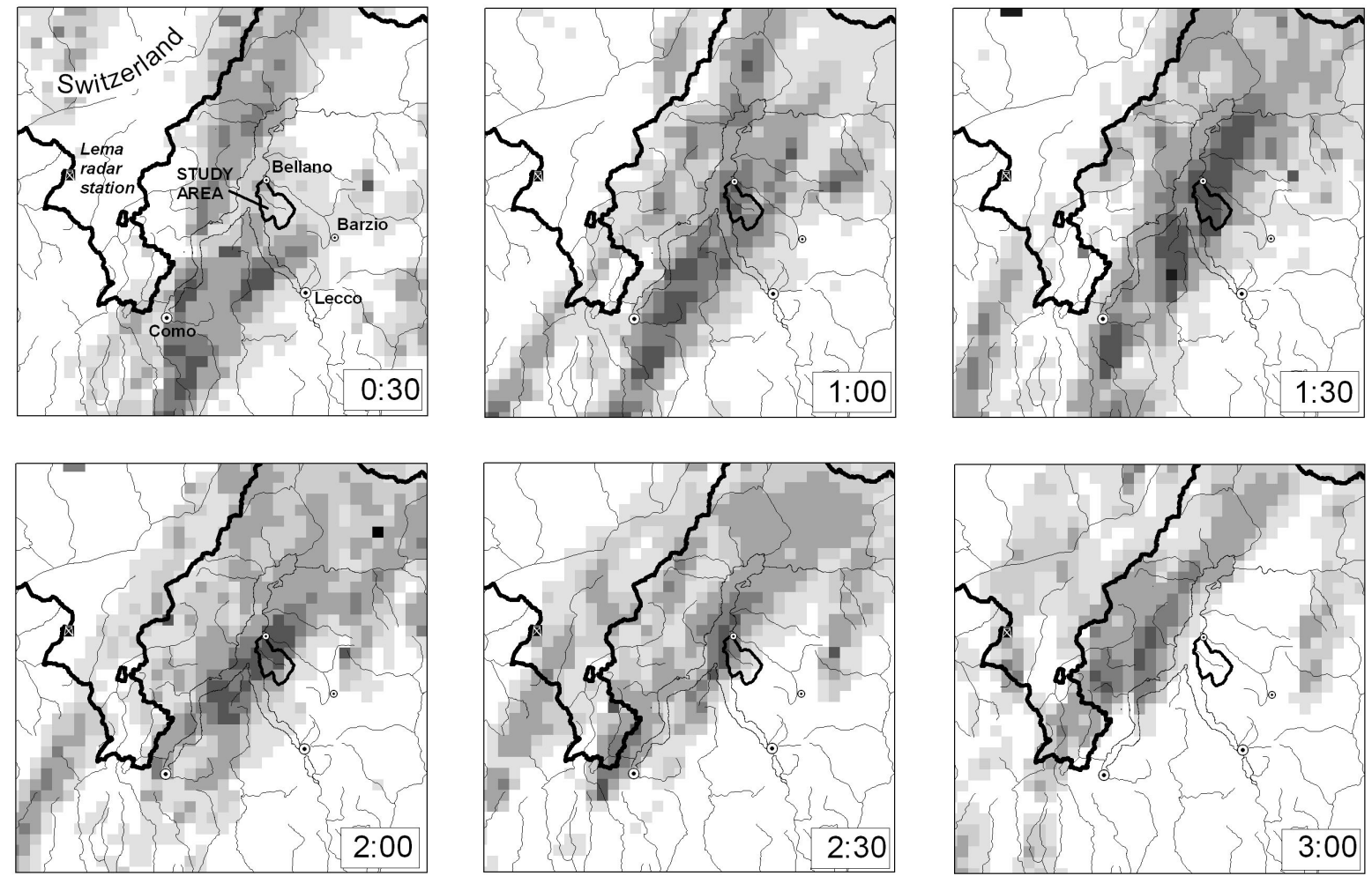

\section{Rainfall intensity $(\mathrm{mm} / \mathrm{h})$}
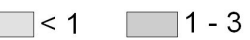

$3-10$

$30-100$

$>100$

Fig. 4. Radar maps of rainfall intensity at $30 \mathrm{~min}$ time interval from 00:30 LT to 03:00 LT of 28 June 1997. The Mt. Lema radar station and the Bellano and Barzio rain gauges are located on the map. The movement of the storm from SSE to NNW can be recognised.

estimate, the Swiss Meteorological Institute performs an automatic calibration of the instruments to verify the stability of all important components and a software processing to correct the influence of meteorological processes and orography. Several corrections are applied on radar data (Held and Joss, 1994), namely: (1) correction for the influence of the vertical profile of reflectivity combined with reduced visibility caused by geometrical shielding by mountains and earth cur- vature, (2) elimination of clutter echoes (including the interpolation of weather echoes over the residual holes remaining after clutter elimination), i.e. of the contamination of measured echo (reflectivity, signal) by reflections of the emitted radiation at the ground, (3) reduction of concentric structures around the radar and caused by the bright band and (4) reduction of small scale variability by applying spatial smoothing to all data. To optimise these corrections, the correlation 


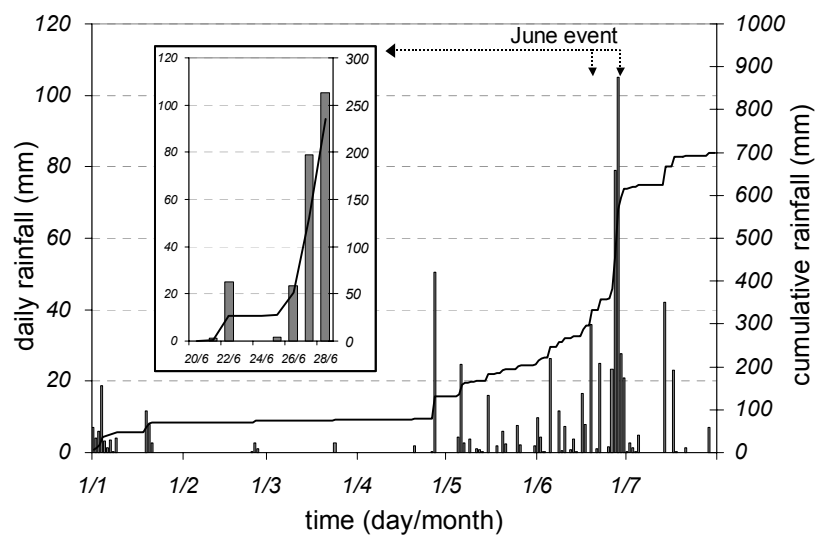

Fig. 5. Plot of daily rainfall and cumulative rainfall for Bellano rain gauge station from 1 January to 31 August 1997; the 27-28 rainfall event followed a 2-months period of prolonged low intensity precipitation. Insert in the figure represents a zoom of rainfall data for the week including the event.

coefficient was used as a criterion for the improvement obtained. The Swiss Meteorological Institute has determined a correlation between radar data over a set of 470 rain gauges with the data of the rain gauges, i.e. an independent set of data at ground-level.

In order to assess the reliability of radar rainfall intensities over the study area, a comparison of the two sets of intensities for the rainfall event at the stations of Bellano and Barzio was performed (Fig. 3). Rain-gauge data satisfactory fit the range of values given by radar data, and approximately follow the calculated mean value of radar intensity. This is especially true for the Bellano rain-gauge station. This result supports the use of radar derived rainfall intensities for application in landslide triggering assessment, at least in this special case.

The high intensity-short duration rainstorm hit the study area in the night between 27 and 28 June 1997. The thunderstorm reached the southern part of the study area at 01:00 LT, moving northerly (Fig. 4). From 01:30 to 02:30 LT the rainstorm passed through Bellano, as the rain gauge station correctly recorded with measured intensity of $39 \mathrm{~mm} / \mathrm{h}$ between 01:00 and 02:00 LT, and $46 \mathrm{~mm} / \mathrm{h}$ between 02:00 and 03:00 LT (Fig. 3). Prolonged low-intensity precipitation characterised the 2 preceding months, with about $280 \mathrm{~mm}$ of rain (Fig. 5). Then, even if the days immediately before the event were characterised by moderate rainfalls $(50 \mathrm{~mm}$ of rain in one week), the initial soil moisture should have been high at the beginning of the high intensity rainstorm. The statistical analysis of historical rainfall data indicates that the event was exceptional if compared with the previous 50 years of precipitation, especially for short duration events. The calculated recurrence time ranges from 75 years for the short (1 to $2 \mathrm{~h}$ ) to 25 years for a longer duration time (1 to 23 days) (Fig. 6).

A detailed landslide inventory has been prepared for the event with 147 landslides mapped in this area, all classified

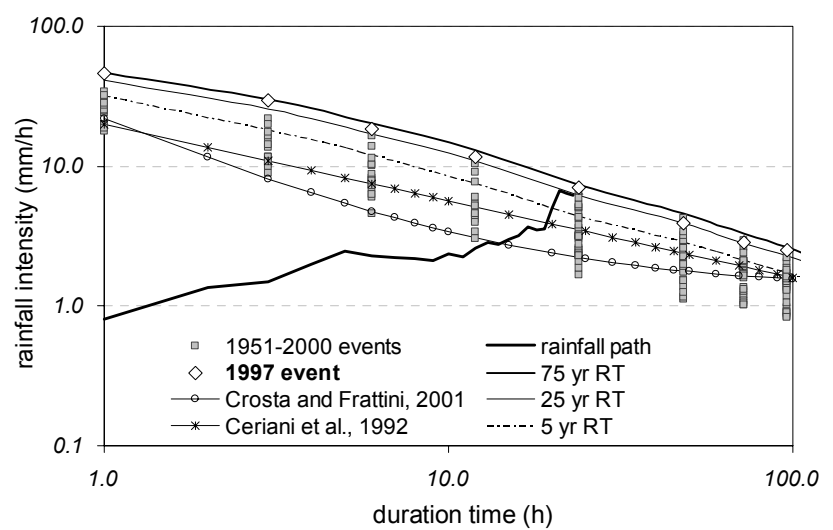

Fig. 6. Recurrence time of rainfall events at Bellano rain gauge compared with the 27-28 June 1997 maximum intensities and rainfall pattern (defined as cumulative rainfall normalized by rainfall duration). Two rainfall thresholds for shallow landslide triggering in Alpine areas are reported (Ceriani et al., 1992; Crosta and Frattini, 2001).

as soil slips and soil slips-debris flows (Campbell, 1975).

Field studies showed that the depth of failure surface was $60 \pm 40 \mathrm{~cm}$. The majority of landslides were initiated within colluvium in hollows and open slopes with a slope steepness ranging from $35^{\circ}$ to $50^{\circ}$.

\section{Modelling hydrologic processes}

Mountain slopes are covered with soils characterised by different physical and mechanical properties. These soils are also characterised by different hydrological conditions both in function of space and time. As a consequence, different hydrological models can be coupled with slope stability models in function of the initial conditions and of the type of rainfall event (low intensity prolonged rainfall or high intensity short duration rainfall). Three simplified hydrological models have been considered in this study, namely: a steady state model, a "piston flow" infiltration model, and a pressure head diffusive model.

Iverson's (2000) modelling framework considers the pore pressure response of shallow soils to rainfall. Approximations of the Richards equation valid for different time scale and different antecedent condition are proposed. The Richards equation can be written as:

$$
\begin{aligned}
& \frac{\partial \psi}{\partial t} \frac{\partial \theta}{\partial \psi}=\frac{\partial}{\partial x}\left[k_{L}(\psi)\left(\frac{\partial \psi}{\partial x}-\sin \alpha\right)\right]+ \\
& \frac{\partial}{\partial y}\left[k_{L}(\psi)\left(\frac{\partial \psi}{\partial y}\right)\right]+\frac{\partial}{\partial z}\left[K_{Z}(\psi)\left(\frac{\partial \psi}{\partial Z}-\cos \alpha\right)\right],
\end{aligned}
$$

where $x, y$ and $z$ are the axes of a reference coordinate system with $z$ normal to the slope, $\psi$ is the groundwater pressure head, $\theta$ is the soil volumetric water content, $t$ is the time, $\alpha$ is the slope angle and $K_{L}, K_{Z}$ are the hydraulic conductivity in lateral and normal direction, respectively. 

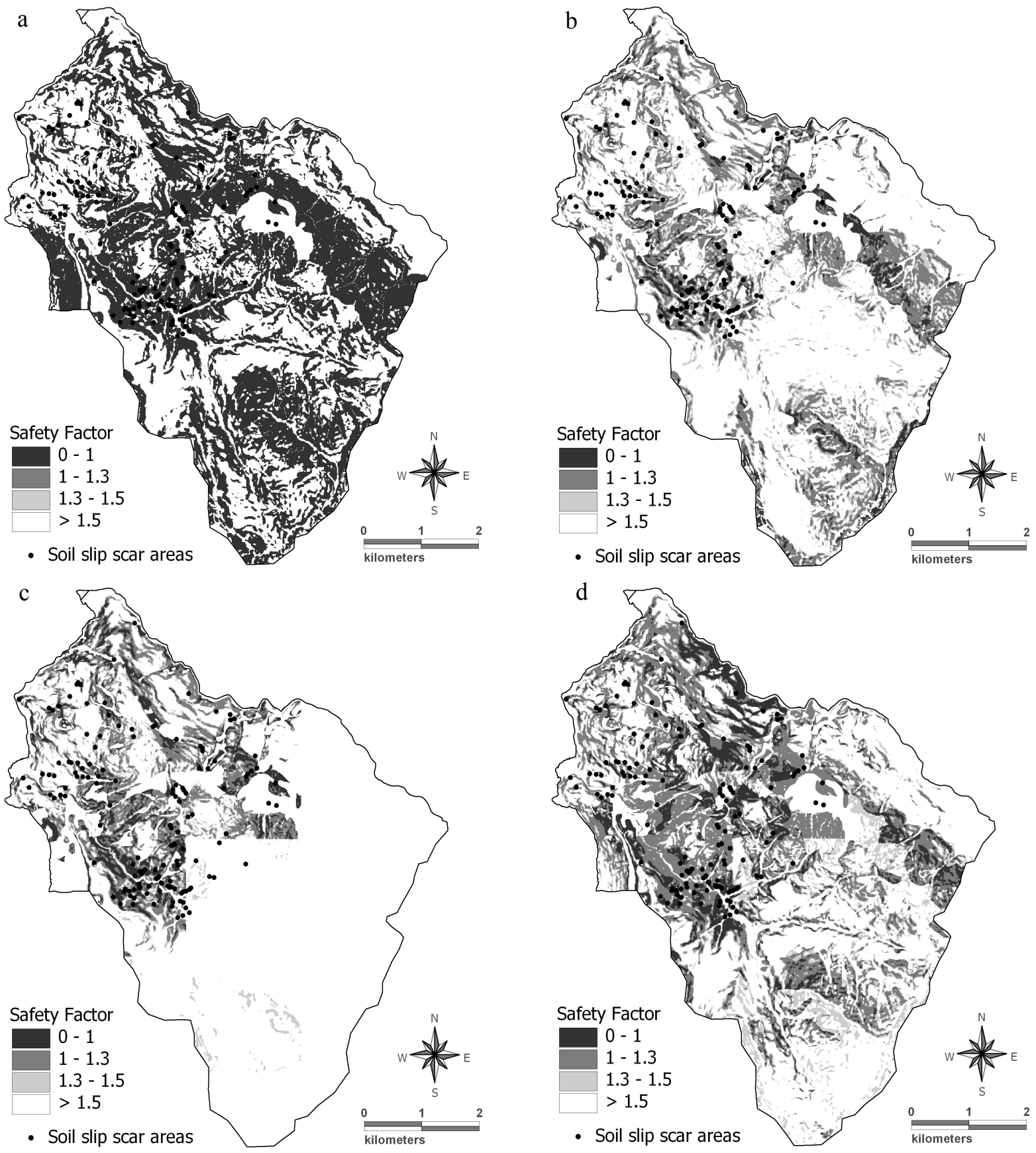

Fig. 7. Slope stability maps from the simulation with different hydrological models: (a) steady state model (SSM); (b) piston flow model with uniform precipitation (PFM_UNI); (c) piston flow model with distributed precipitation (PFM_DIS); (d) diffusive model with distributed precipitation (DM_DIS). Results for the diffusive model (DM_DIS) are relative to the maximum soil thickness. Areas with different computed safety factors are reported.

For long rainfall duration, a model is developed to describe quasi-steady state pressure in response to low-intensity rainfall over periods ranging from days to months. Under this condition Eq. (1) reduces to:

$\frac{\partial}{\partial z^{*}}\left[K_{z}^{*}\left(\frac{\partial \psi^{*}}{\partial z^{*}}-\cos \alpha\right)\right]=0$, where $z^{*}$ is the slope-normal direction, $z$, normalised by the depth of failure surface, $H ; K^{*}$ is the slope-normal conductivity normalised with reference to the saturated conductivity $K_{s}$.

A further approximation that can reduce the model to the steady flow condition described by Montgomery and Dietrich (1994) is valid under the following conditions: (1) 
a

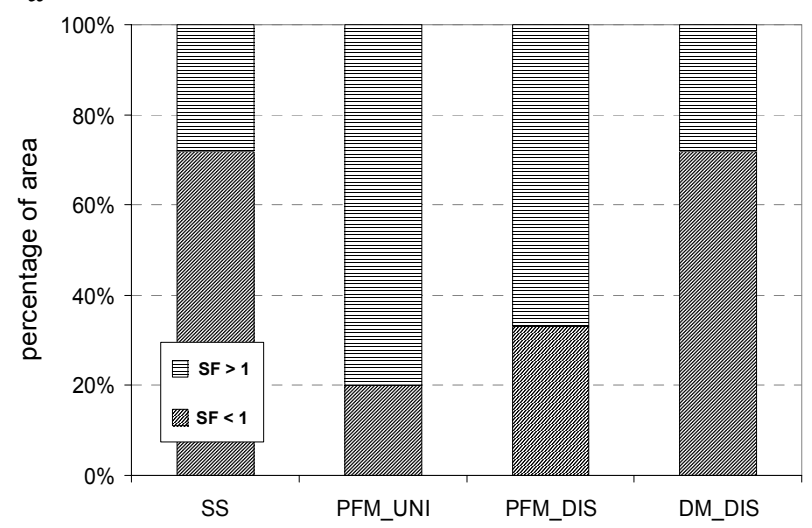

b

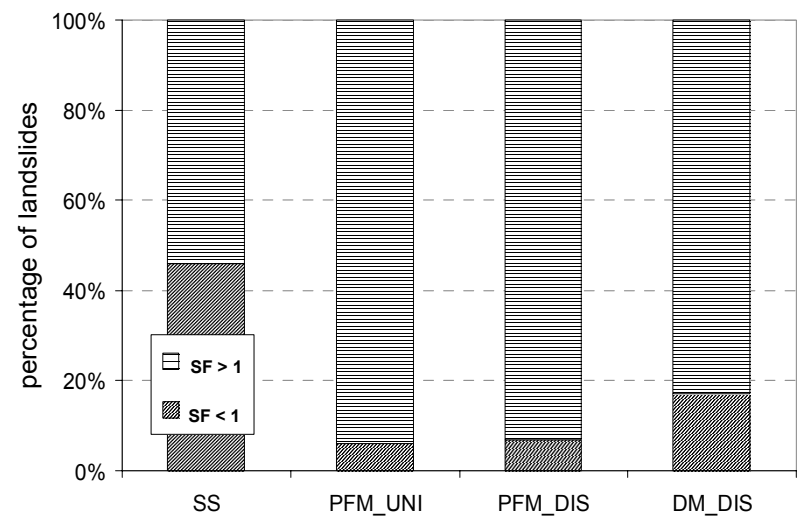

c

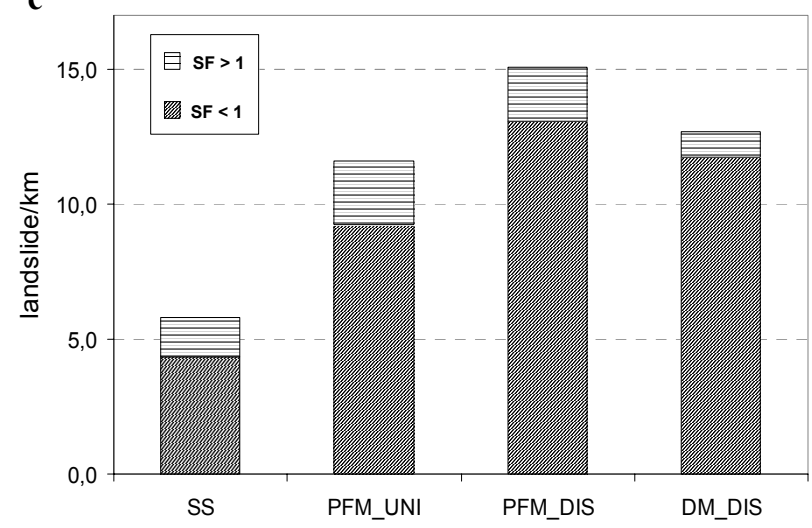

Fig. 8. Slope stability simulation results with different hydrological models (SSM, steady state model; PFM_UNI, piston flow model with uniform precipitation; PFM_DIS, piston flow model with distributed precipitation; DM_DIS, diffusive model with distributed precipitation); (a) \% of total area modelled as stable $(S F>1)$ or unstable $(S F<1)$; (b) \% of observed landslides correctly or incorrectly classified by the model; (c) landslide density $\left(1 \mathrm{~s} / \mathrm{km}^{2}\right)$ for correctly and incorrectly classified landslides with respect to the results of the model (i.e. $S F<1$ and $S F>1$, respectively). Results for the diffusive model (DM_DIS) are relative to the maximum soil thickness.

very long rainfall duration, (2) very low rainfall intensity, (3) very shallow depth of the impermeable bed, (4) strongly anisotropic conductivity (slope-normal component $>$ slopeparallel component). Under these conditions the groundwater flux above a reference depth $\delta$ can be calculated with Darcy's law for slope-parallel flow.

The relative solution for the Richards equation is:

$\psi=(z-\delta) \cos \alpha+\frac{i_{z}}{K_{L}} \frac{A}{b} \cot \alpha$,

in which $i_{z}$ is the infiltration rate in the $z$ direction at the ground surface, $A$ is the drainage area and $b$ is the width of the slope element over which the flux is measured.

The water table depth above the impermeable bed is:

$\delta-d=\frac{i_{z}}{K_{L}} \frac{A}{b \sin \alpha}$

and the saturation degree $\theta=\frac{\delta-d}{\delta}$ is expressed as:

$\theta=\min \left(\frac{q}{T_{L}} \frac{\alpha}{\sin \alpha}\right)$

where the transmissivity, $T_{L}$, is equal to $\delta \cdot K_{L}$ in an homogeneous soil; $q$, the steady recharge, is equal to $i_{z}$ over long period in steady state conditions and $\alpha$, the specific catchment is equal to the $A / b$ ratio. This is the equation used by Montgomery and Dietrich (1994) in their model. This model allows to determine the critical groundwater depth $(d)$ in response of the net steady state recharge $(q)$ distributed on the contributing area $(A)$.

For short time periods other approximations of the Richards equation are developed. These approximations are valid for the case of shallow soils and a rainfall time shorter than the time necessary for strong lateral pore pressure transmission. In this case, only the vertical pore pressure transmission affects significantly the pore pressure water head. This transmission is due both to water flux and to pressure diffusion.

In the case of initially dry soils the diffusion term can be neglected, and Richards equation can be reduced to a simple form that describes the flux of water within the soil:

$\frac{\partial \psi^{*}}{\partial t^{*}}+\frac{\partial \psi^{*}}{\partial Z^{*}}\left(\cos ^{2} \alpha \frac{I_{z}}{K_{z}} \frac{C_{0}}{C(\psi)} \frac{d K_{z}^{*}}{d \psi^{*}}\right)=0$,

where $\psi^{*}$ is the groundwater pressure head normalized by the depth of failure surface. $t^{*}$ is a dimensionless time, equal to $t D_{0} / H^{2}$, where $D_{0}=K_{s} / C_{0} . C_{0}$ is the minimum value of $C(y)=d \theta / d \psi$, i.e. the change in volumetric water content per unit change in pressure head, close to storage coefficient. $D_{0}$ represents the maximum diffusivity governing transmission of pressure head, and it is reached in proximity of saturation. This equation corresponds to the "piston-flow" wetting front model described by Green and Ampt (1911) for infiltration. This equation can be solved with different approaches: successive iteration (Mein and Larsen, 1973; Chow et al., 1988; and others), graphical approach (Chu, 1978) or explicit approximated solutions (Salvucci and Entekhabi, 1994; Srivastava et al., 1996). Salvucci and En- 

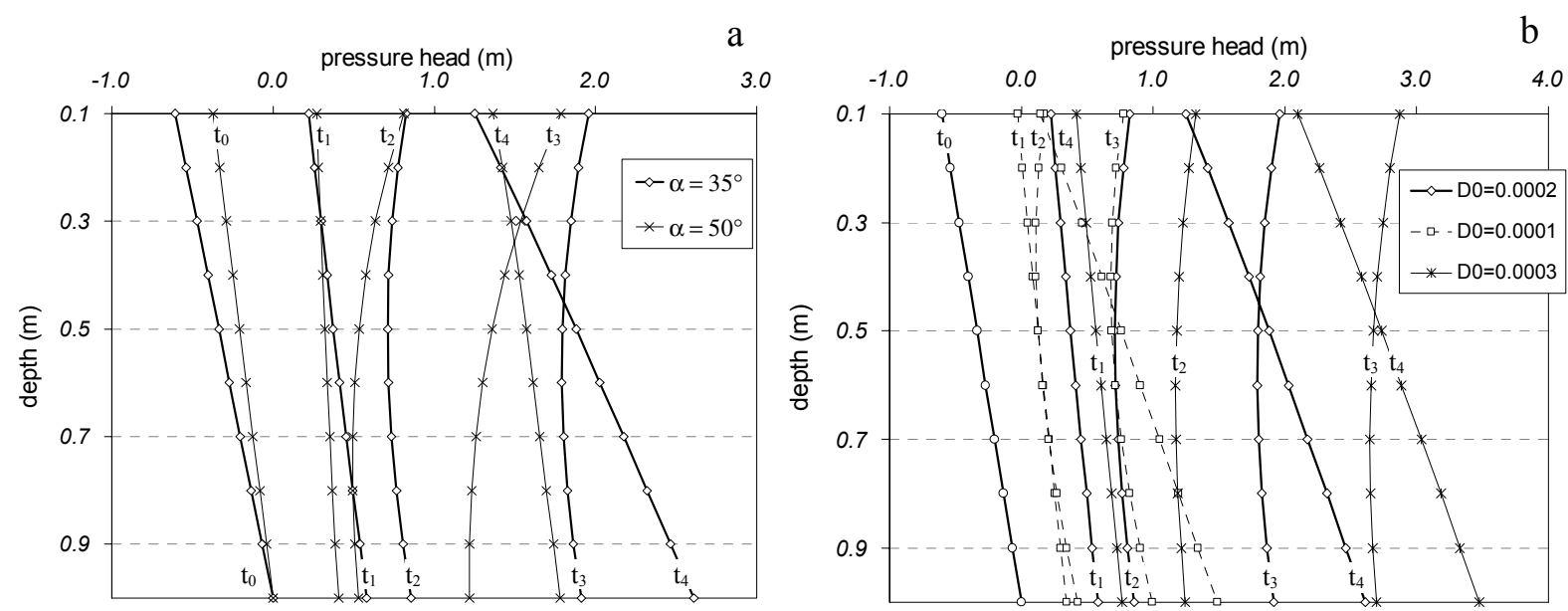

Fig. 9. Groundwater pressure head, $\psi(Z, t)$ at depth $Z$ and time $t$ as simulated by diffusive model with distributed rainfall: (a) results with different slope angles and constant diffusivity $\left(D_{0}=00002 \mathrm{~m}^{2} / \mathrm{s}\right)$; (b) results with constant slope angle $\left(\alpha=35^{\circ}\right)$ and different diffusivity values. Values are plotted at different time steps $t_{1}=01: 00 \mathrm{LT} ; t_{2}=02: 00 \mathrm{LT} ; t_{3}=03: 00 \mathrm{LT} ; t_{4}=04: 00 \mathrm{LT}$ of $28 \mathrm{June}$ starting from $t_{0}=$ 21:00 LT of 27 June.

tekhabi (1994) suggest the following solution:

$$
\begin{aligned}
\frac{i}{K_{s}} & =\frac{\sqrt{2}}{3}\left(\frac{t}{t+\chi}\right)^{-1 / 2}+\frac{2}{3}-\frac{\sqrt{2}}{6}\left(\frac{t}{t+\chi}\right)^{-1 / 2} \\
& +\frac{1-\sqrt{2}}{3}\left(\frac{t}{t+\chi}\right)
\end{aligned}
$$

with

$\chi=\frac{\left(h_{s}-h_{f}\right)\left(\theta_{s}-\theta_{0}\right)}{K_{s}}$,

where $h_{s}$ and $h_{f}$ are the pressure head at the topographic surface and at the wetting front respectively, $\theta_{s}$ is the saturated volumetric water content and $\theta_{0}$ is the initial soil moisture. The maximum estimated error in $i / K_{S}$ is approximately 0.02 to 2\% (Salvucci and Entekhabi, 1994).

The gravity flux term can be neglected for wet initial conditions, yielding a pressure head diffusion equation, in the form:

$\frac{\partial \psi}{\partial t}=D_{0} \cos ^{2} \alpha \frac{\partial^{2} \psi}{\partial Z^{2}}$.

A solution is possible with the appropriate boundary conditions:

$\psi(Z, 0)=\left(Z-d_{z}\right) \beta$,

$\frac{\partial \psi}{\partial Z}(\infty, t)=\beta$,

$\frac{\partial \psi}{\partial Z}(0, t)=\left\{\begin{array}{rl}-I_{z} / K_{z}+\beta & : t \leq T \\ \beta & : \quad t>T\end{array}\right.$,

where $d_{z}$ is the water table depth (in vertical direction, $Z$ ), $T$ is the rainfall duration and $\beta$ is a constant that expresses the initial steady state pressure head distribution, being $\beta=$ $\cos ^{2} \alpha-\left(I_{z} / K_{z}\right)_{\text {steady }}$.
With these conditions the solution of the diffusion equation is (Iverson, 2000):

$$
\begin{aligned}
& \frac{\psi}{Z}(Z, t \leq T)=\beta\left(1-\frac{d_{z}}{Z}\right)+\frac{I_{z}}{K_{z}}\left[R\left(t^{*}\right)\right] \\
& \frac{\psi}{Z}(Z, t>T)=\beta\left(1-\frac{d_{z}}{Z}\right)+\frac{I_{z}}{K_{z}}\left[R\left(t^{*}-T^{*}\right)\right]
\end{aligned}
$$

with:

$$
\begin{aligned}
& R\left(t^{*}\right)=\sqrt{\frac{t^{*}}{\pi}} \exp \left(-\frac{1}{t^{*}}\right)-\operatorname{erfc}\left(\frac{1}{\sqrt{t^{*}}}\right) \\
& t^{*}=\frac{t}{Z^{2}}\left(4 D_{0} \cos ^{2} \alpha\right) \\
& T^{*}=\frac{T}{Z^{2}}\left(4 D_{0} \cos ^{2} \alpha\right)
\end{aligned}
$$

where $R\left(t^{*}\right)$ is a pressure head response function, $t^{*}$ and $T^{*}$ are normalised time and rainfall duration, respectively.

\section{Modelling landslide process}

In order to model the slope failure within a distributed regional-scale framework, a one-dimensional infinite-slope stability analysis is the preferred tool (Montgomery and Dietrich,1994; Wu and Sidle, 1995; Borga et al., 1998; Pack et al., 1998; Iverson, 2000; Crosta and Frattini, 2001; Morrissey et al., 2001). This model is based on a simplified landslide geometry that assumes a planar slip surface on a infinitely extended planar slope, both laterally and distally. These assumptions are generally valid in case of very shallow landslides having a small depth in comparison to length and width of landslides and slopes. This seems a reasonable condition for the processes observed in the study area.

Following the Mohr-Coulomb criterion, a failure at a certain depth $Z$ occurs when the acting stresses (i.e. the downslope component of the gravitational stress) equal the resisting 
stresses due to friction and cohesion. In other words, failure occurs when the Safety Factor, $S F$, is equal to 1 . Considering that Safety Factor is time dependent, it is useful to divide it into a time-varying component $S F^{\prime}(Z, t)$ and a steady state component $S F_{0}(Z)$ (Iverson, 2000):

$$
\begin{aligned}
& S F(Z, t)=S F_{0}(Z)+S F^{\prime}(Z, t) \\
& S F_{0}(Z)=S F_{f}(Z)+S F_{c}(Z)-\frac{\psi_{0}(Z) \gamma_{w} \tan \varphi}{\gamma_{s} Z \sin \alpha \cos \alpha}
\end{aligned}
$$

with:

$$
\begin{aligned}
& S F_{f}(Z)=\frac{\tan \varphi}{\tan \alpha} \\
& S F_{c}(Z)=\frac{c}{\gamma_{s} Z \sin \alpha \cos \alpha}
\end{aligned}
$$

where $\varphi$ is the soil friction angle, $c$ is the soil cohesion, $\gamma_{s}$ is the soil unit weight, $\gamma_{w}$ is the groundwater unit weight.

\section{Analysis}

Three different grid-based distributed hydrological models have been implemented in ArcInfo Macro Language (AML by ESRI): a steady state model (Montgomery and Dietrich, 1994), a transient "piston-flow" wetting front model (Green and Ampt, 1911), and a transient diffusive model (Iverson, 2000). These models have been coupled with an infinite slope stability analysis and applied to simulate the triggering of shallow landslides due to the rainfall event of $27-$ 28 June. The calibration was essentially performed on the basis of prior information about soil and vegetation, with adjustments made to improve the distribution of computed Safety Factor with respect to the actual distribution of triggered landslides. A more hydrologically sound calibration was not possible due to the unavailability of data like discharge and other internal state model variables (water table levels, soil moisture level, etc.).

Spatial discretization of the model was obtained splitting the study area into a number of squared grid elements, with a size of $10 \mathrm{~m}$. An hydrologically correct digital elevation model (Hutchinson, 1989) was realized with ArcInfo's topogrid interpolation method, starting from contour lines with $10 \mathrm{~m}$ of vertical spacing. Elaboration of DEM data permitted to calculate slope gradient and the drainage area for each grid cell: the slope for the cell was calculated from the $3 \times 3$ neighbourhood using the average maximum technique (Burrough, 1986); the drainage area was calculated using the multiple direction flow method (Quinn et al., 1991).

Soil properties needed for stability analysis have been obtained indirectly from the soil typology recognised on field. Representative samples have been collected and analysed in laboratory (Table 1), and permeability tests with Guelph Permeameter have been performed in the field (Table 2). These data were compared with literature data (Rawls and Brakensiek, 1989) to estimate a range of liable values to calibrate the models (Table 3).
The transient "piston-flow" model needs the estimation of other hydrological parameters. The initial soil moisture content $\theta_{i}$ was empirically evaluated from the antecedent precipitation; the effective porosity, $\theta_{e}$, was derived from literature (Rawls and Brakensiek, 1989); the capillary pressure head at the wetting front $h_{f}$ was calculated with literature formulae (Neuman, 1976; Brakensiek and Onstad, 1977); the pressure head at the topographic surface, $h_{s}$, was simply taken to be equal to the ponding depth, and overlooked during the analysis.

The transient diffusive model needs the estimation of the maximum hydraulic diffusivity, $D_{0}$, that was calculated using soil moisture characteristic functions (Brooks and Corey, 1964; Van Genuchten, 1980; Fredlund and Xing, 1994), and then calibrated during the simulation.

The steady state model was originally developed by Montgomery and Dietrich (1994) to assess the susceptibility of slope to instability and to put in evidence the role of topographic hollows in landslide triggering. The model was not specifically developed to simulate single short time-high intensity rainfall events. It is based, in fact, on the hypothesis of groundwater table rising from the bottom to the top, with runoff eventually generated by saturation excess overland flow (Dunne and Black, 1970). The model needs a net steady state recharge, that was calculated averaging the rainfall occurred during the antecedent 4 rainy days. SCS method (Soil Conservation Service, 1972) was used in order to calculate abstraction due to surface runoff. The resultant recharge value was $1.7 \mathrm{~mm} / \mathrm{h}$. The output of the hydrological model is the height of groundwater table over an impermeable layer, that normally is represented by underlying bedrock. Using this groundwater table height within the stability model it is possible to calculate the Safety Factor at the contact between soil and underlying bedrock.

The result of the application is shown in Figs. $7 \mathrm{a}$ and 8. The $46.0 \%$ of the area was classified as unstable $(F S \leq 1.0)$, and the $72 \%$ of the actual landslides were correctly localised within this area, with a landslide density of $4.6 \mathrm{ls} / \mathrm{km}^{2}$. Landslide density, for correctly classified landslides, is the ratio between the number of observed landslides (including only the source areas) and the total area classified as unstable by the model. The computation of misclassified landslide density (landslides located out of areas classified as unstable by the model) can be useful to evaluate the error relative to the use of a specific model (Fig. 8c).

The piston-flow wetting front model (Green and Ampt, 1911) simulates the infiltration of water from the surface. A considerable potential difference exists at the wetting front between the underlying unsaturated layers with negative pore pressure, due to soil suction, and the upper saturated layers with positive hydrostatic pressure. This abrupt drop of stabilising negative pressure (Fredlund, 1987) can be a triggering factor of slope failure at the wetting front (Crosta, 1998). The output of this model is the time-dependent depth of the wetting front from the surface, $Z_{w}(t)$. Using this depth within the stability model it is possible to calculate the Safety Factor at the wetting front during the rainstorm. Spatially uni- 
Table 1. Soil properties from laboratory tests of representative samples

\begin{tabular}{ccccccc}
\hline Sample & Soil typology & U.S.C.S. & \% Gravel & \% Sand & \% Clay and silt & $\varphi\left({ }^{\circ}\right)^{1}$ \\
\hline 1 & Shallow colluvial soils & Silty gravel & 70 & 8 & 22 & 25.4 \\
2 & Shallow colluvial soils & Sand with silt & 23 & 39 & 38 & 23.2 \\
3 & Shallow colluvial soils & Silty poor sorted sand & 38 & 33 & 29 & 23.6 \\
4 & Colluvial soils & Silty gravel & 53 & 21 & 26 & 24.6 \\
5 & Glacial deposits & Sand with silt & 25 & 34 & 39 & 23.3 \\
6 & Colluvial soils & Silty poor sorted sand & 29 & 36 & 35 & 24.8 \\
7 & Glacial deposits & Silty gravel & 50 & 27 & 23 & 25 \\
\hline
\end{tabular}

${ }^{1}$ Friction angle, $\varphi\left(^{\circ}\right)$ derived from direct shear tests with material finer than $2 \mathrm{~mm}$.

Table 2. Values of hydraulic conductivity as by in situ permeability tests

\begin{tabular}{cccc}
\hline Site & Depth $(\mathrm{m})$ & $K_{S}(\mathrm{~cm} / \mathrm{s})$ & Soil typology \\
\hline 1 & 0.38 & $3.25 \cdot 10^{-4}$ & Colluvial soils \\
2 & 0.25 & $7.34 \cdot 10^{-4}$ & Shallow colluvial soils \\
3 & 0.25 & $9.90 \cdot 10^{-4}$ & Shallow colluvial soils \\
4 & 0.31 & $5.83 \cdot 10^{-3}$ & Colluvial soils \\
5 & 0.48 & $5.77 \cdot 10^{-5}$ & Glacial deposits \\
6 & 0.30 & $4.90 \cdot 10^{-2}$ & Slope debris \\
$7 \mathrm{a}$ & 0.30 & $2.58 \cdot 10^{-3}$ & Shallow colluvial soils \\
$7 \mathrm{~b}$ & 0.60 & $7.41 \cdot 10^{-4}$ & Colluvial soils \\
$8 \mathrm{a}$ & 0.33 & $2.94 \cdot 10^{-4}$ & Glacial deposits \\
$8 \mathrm{~b}$ & 0.70 & $6.46 \cdot 10^{-5}$ & Glacial deposits \\
\hline
\end{tabular}

form values of hourly rainfall intensity from Bellano rain gauge station (Fig. 3) and distributed 30 min radar rainfall intensities (Fig. 4) have been used to simulate the event from 09:00 LT of the 27 to 05:00 LT of the 28 . Only $6.0 \%$ of the area was classified as unstable using uniform rainfall intensities (Figs. 7b and 8). Only 20.0\% of the actual landslides were classified within this area, with a density of $9.2 \mathrm{ls} / \mathrm{km}^{2}$. The total unstable area amounts to $7.6 \%$, with the $33.5 \%$ of actual landslides and a density of $13.1 \mathrm{ls} / \mathrm{km}^{2}$ using the distributed rainfall (Figs. 7c and 8). The diffusivity model (Iverson, 2000) simulates the transmission and distribution of pore pressure in wet conditions within the soil profile during and after the rainstorm. The output of the model is the groundwater pressure head, $\psi(Z, t)$ at depth $Z$ and time $t$ (Fig. 9a). For the application, we decided to calculate three values of pressure head in every grid cell for every time step; these values correspond to $1 / 3,2 / 3$ and $3 / 3$ of the estimated soil depth. Distributed $30 \mathrm{~min}$ radar rainfall intensities have been used for the modelling. After calibration a diffusivity of $2 \cdot 10^{-4} \mathrm{~m}^{2} / \mathrm{s}$ was selected, giving the following results:

- 1/3 of the soil depth: $0.005 \%$ of unstable area with $0 \%$ of actual landslides;

- $2 / 3$ of the soil depth: $3.6 \%$ of unstable area with $18.5 \%$ of landslides and a density of $22.2 \mathrm{ls} / \mathrm{km}^{2}$;
- 3/3 of the soil depth: $17.5 \%$ of unstable area with $72.3 \%$ of landslides and a density of $11.8 \mathrm{ls} / \mathrm{km}^{2}$ (see Figs. $7 \mathrm{~d}$ and 8).

\section{Discussion}

Model evaluation was carried out through the analysis of computed Safety Factor with respect to the actual distribution of triggered landslides. The advantage of this approach is that the evaluation is distributed, differently from most of the traditional evaluation strategies (Beven, 2001). The main disadvantage is that slope stability is an indirect estimator of hydrological models and introduce additional sources of uncertainty. In practice, an absolute evaluation of the hydrological model is not possible. On the other hand, the use of the same equations for slope instability permits a relative evaluation and confrontation of the different models. This is the main goal of this paper.

Source of errors in our modelling can therefore be classified as:

- areas modelled as stable with actual landslides;

- areas modelled as unstable without actual landslides.

From a geomorphologic point of view, the first type of error indicate that the model is not able to gather the actual triggering condition. This can be due both to the hydrological model (incorrect rainfall input, wrong hydrological parameters, violation of model assumptions, oversimplification of hydrological processes, etc.), and to the stability model (incorrect soil properties, insufficient or erroneous description of slope morphology, violation of model assumptions, etc.). As said before, a relative discrimination between these source of errors can be performed with confrontation of different hydrological models using the same stability equations. The second type of error is a minor one in the sense that the absence of a landslide does not mean that a certain slope cannot experience landsliding under slightly different conditions in the range of model's uncertainty. As we need to be conservative in managing natural hazards, this second error is far less important than the first one.

As a consequence, in order to evaluate the models, we primarily need to assess the probability to classify as stable an 
Table 3. Range of values for soil parameters as adopted in the simulations. Soil classes are as in Fig. 2

\begin{tabular}{lccccc}
\hline Soil typology & $d(\mathrm{~m})$ & $\gamma_{s}\left(\mathrm{kN} / \mathrm{m}^{3}\right)$ & $\varphi\left(^{\circ}\right)$ & $c\left(\mathrm{kN} / \mathrm{m}^{2}\right)$ & $K_{S}(\mathrm{~cm} / \mathrm{s})$ \\
\hline Shallow colluvial soils & $0.3-0.7$ & $17-19$ & $22-27$ & $3.0-4.0$ & $2 \cdot 10^{-4}-8 \cdot 10^{-4}$ \\
Colluvial soils & $0.7-1.5$ & $17-19$ & $22-27$ & $4.5-5.5$ & $2 \cdot 10^{-4}-8 \cdot 10^{-4}$ \\
Slope debris & $0.5-1.0$ & $17-19$ & $35-45$ & $2.0-3.0$ & $5 \cdot 10^{-3}-2 \cdot 10^{-2}$ \\
Alluvial deposits & $1-3$ & $17-19$ & $22-27$ & $3.5-4.5$ & $5 \cdot 10^{-4}-1 \cdot 10^{-3}$ \\
Glacial deposits & $1-3$ & $17-19$ & $22-27$ & $3.0-4.0$ & $5 \cdot 10^{-5}-5 \cdot 10^{-4}$ \\
\hline
\end{tabular}

Table 4. Model results and associated probabilities for the different models: steady state model with constant recharge (SSM); piston flow model with uniform precipitation from Bellano rain-gauge (PFM_UNI); piston flow model with $1 \times 1$ km distributed precipitation from Mount Lema radar station (PFM_DIS); diffusive model with $1 \times 1 \mathrm{~km}$ distributed precipitation from Mount Lema radar station (DM_DIS).

\begin{tabular}{lcccc}
\hline & SSM & PFM_UNI & PFM_DIS & DM_DIS \\
\hline Modelled unstable area (\% of total area) & $46.5 \%$ & $6.0 \%$ & $7.6 \%$ & $17.5 \%$ \\
Landslides within unstable area $(\%$ of landslides) & $72.0 \%$ & $20,0 \%$ & $33.5 \%$ & $72.3 \%$ \\
Landslide density in unstable area $\left(1 \mathrm{~s} / \mathrm{km}^{2}\right)$ & 4.3 & 9,2 & 13.1 & 11.8 \\
P[model stable areas] = P[S] & 0.5350 & 0.9400 & 0.9240 & 0.8250 \\
P[model unstable areas] = P[I] & 0.4650 & 0.0600 & 0.0760 & 0.1750 \\
P[find actual lanslides] = P[F] & 0.0046 & 0.0046 & 0.0046 & 0.0046 \\
P[find no landslides] = P[NF] & 0.9954 & 0.9954 & 0.9954 & 0.9954 \\
P[stable with landslide]=P[S|F] & 0.0013 & 0.0037 & 0.0031 & 0.0013 \\
P[stable with no landslide]=P[S|NF] & 0.5337 & 0.9362 & 0.9209 & 0.8237 \\
P[unstable with landslide]=P[I|F] & 0.0033 & 0.0009 & 0.0015 & 0.0033 \\
P[landslide within stable area] = P[F|S] & $1.12 \cdot 10^{-5}$ & $1.82 \cdot 10^{-5}$ & $1.54 \cdot 10^{-5}$ & $7.20 \cdot 10^{-6}$ \\
P[landslide within unstable area]=P[F|I] & $3.32 \cdot 10^{-5}$ & $7.15 \cdot 10^{-5}$ & $9.75 \cdot 10^{-5}$ & $8.86 \cdot 10^{-5}$ \\
Quality index & 2.9 & 3.9 & 6.1 & 12.3 \\
\hline
\end{tabular}

area that, in reality, is unstable. In order to take in account the spatial uncertainty related with landslide mapping, a reasonable buffer of $1200 \mathrm{~m}^{2}$ was created for each landslide. The total area occupied by instabilities amounts to almost $175000 \mathrm{~m}^{2}$. This gives a total probability to have a landslide in the area, $\mathrm{P}[\mathrm{L}]$, of 0.0046 . The probability that a single grid element is stable $(\mathrm{P}[\mathrm{S}])$ or unstable $(\mathrm{P}[\mathrm{I}])$ is a result of the model. Comparing these probabilities with landslide distribution we obtain the probability that the grid element is stable or unstable giving the fact that there is an actual landslide on it $(\mathrm{P}[\mathrm{S} \mid \mathrm{L}]$ and $\mathrm{P}[\mathrm{I} \mid \mathrm{L}]$, respectively). What we need to assess is the probability to find a landslide giving the fact that the slope is classified as stable $(\mathrm{P}[\mathrm{L} \mid \mathrm{S}])$. This is a conditional probability that can be computed through the Bayes formula:

$P[L \mid S]=\frac{P[L] \cdot P[S \mid L]}{P[S]}$.

This probability will be considered as the error rate of the model. Conversely, the probability to find landslides within areas classified as unstable represent the success rate of the model. The ratio between success and error can be used as quality index for the models.

Table 4 and Fig. 8 summarise the results and the associated probabilities for the different modelling strategies.

The diffusive model works better than the others. It is able to reduce the area simulated as unstable without los- ing the capability to model the actual landslides. The steady state model was not developed to work with short durationhigh intensity rainfall, and so, the processes that presumably triggered the landslides are not modelled with this approach. The good result ( $72 \%$ ) in predicting the location of landslides is due to the large amount of the area modelled as unstable $(46.0 \%)$. This overestimation is due to the fact that the estimated recharge value does not represent a real steady state condition. The error rate amounts to $1.12 \cdot 10^{-5}$, and the quality index is 2.9. This last index clearly reveal the weakness of the model. It shows, in fact, that the probability to correctly model landslides is less than three times the probability to fail.

The analysis of the results of the piston-flow model shows two interesting points. First, the model does not perform as well as the diffusive, and this is the effect of the initial conditions that were probable too wet to permit a good simulation of the infiltration with the Green and Ampt simplification. Due to the high initial moisture content, in fact, the contribution of pressure diffusion cannot be neglected and the simple water flux seems too simplistic. The second interesting issue arises from the comparison of the uniform rainfall model and the distributed rainfall model. The results surprisingly improve by changing the source of rainfall input. The error rate pass from $1.82 \cdot 10^{-5}$ to $1.54 \cdot 10^{-5}$, and the probability 
ratio index changes from 3.9 to 6.1 . The difference between the two models arises even clearly looking at Figs. 7b and 7c.

The diffusive model shows the best performance, with error rate and quality index amounting to $7.20 \cdot 10^{-6}$ and 12.3 , respectively. Despite the difficulties inherent in the calibration of this model, especially for diffusion value to which the model is particularly sensitive (Fig. 9b), it seems to be able to correctly simulate the processes responsible for landslide triggering during such rainfall event. Even the simulation at different depths seems coherent with expected behaviour.

\section{Conclusions}

A comparative analysis of three different grid-based distributed hydrological models was performed to simulate landslide triggering after a rainfall event. The event was characterised by high intensity and short duration rainfalls after a period of prolonged low intensity precipitation. An infinite slope stability model was used to simulate slope failure. The distribution of Safety Factors with respect to the distribution of actual landslides permitted to calibrate the models parameters within a range of liable a priori values. The results are consistent with expected behaviour. The steady state model was not able to discriminate efficiently between stable and unstable areas. The overestimation of unstable areas $(48 \%)$ denotes the impossibility to define a real steady state recharge with a rainstorm like the one we are dealing with. Moreover, even if a more accurate value of recharge would be used, the influence of short duration-high intensity rainfall could not be taken in account. As this seems to be the more common condition for the triggering of these kind of landslides, we can conclude that steady-state hydrological models are poorly suitable for shallow landslides triggering simulation.

The piston-flow model shows a better performance, especially if associated with distributed rainfall. In our specific case, despite the values of intensity were high enough to cause the occurrence of infiltration excess overland flow, the initial soil moisture condition was probably too high, and the contribution of water flux was not primary in pressure transmission. This consideration was corroborated by the performance of the diffusive model, that was able to successfully simulate both the timing and the distribution of actual landslides.

An interesting issue arises from the use of distributed radar rainfall intensities (Crosta et al., 2001; Wieczorek et al., 2001). Despite all the problems and limitation inherent in the application of weather radar in hydrology, data available for the June 1997 event permitted to greatly improve the simulation. In particular, they allowed to explain the non-uniform distribution of landslides within the study area.

Acknowledgements. The authors wish to thank the Swiss Meteorological Institute, and G. Galli in particular, for the availability of radar data. Revision by G. Wieczorek and R. Wilson helped to improve the manuscript. The studies has been partly funded by the DAMOCLES Project, EVG1-1999-00027.

\section{References}

Beven, K. J.: Rainfall - runoff modelling: the primer, Wiley, Chichester (UK), 2001.

Bonham-Carter, G. F., Agterberg, F. P., and Wright, D. F.: Weights of evidence modeling: a new approach to mapping mineral potential, in: Statistical applications in the earth science, (Eds) Agterberg, F. P. and Bonham-Carter, G. F., Geological Survey of Canada Paper 89-9, Ottawa, Canada, 1989.

Borga, M., Dalla Fontana, G., De Ros, D., and Marchi, L.: Shallow landslide hazard assessment using a physically based model and digital elevation data, Environmental Geology, 35, 81-88, 1998.

Brabb, E. E.: Innovative approaches to landslide hazard mapping, Proc. IV Int. Symp. Landslides, Toronto, 1, 307-324, 1984.

Brakensiek, D. L. and Onstad, C. A.: Parameter estimation of the Green and Ampt infiltration equations, Water Resources Research, 13, 1009-1012, 1977.

Brooks, R. H. and Corey, A. T.: Hydraulic properties of porous media, Technical Report Hydrology Paper No. 3, Colorado State University, Fort Collins, CO, 1964.

Brundsen, D., Doornkamp, P. G., Fookes, D. K. C., and Kelly, J. M. H.: Large scale geomorphology mapping and highway engineering design, Q. J. Engineering Geology, 8, 227-253, 1975.

Burrough, P. A.: Principles of Geographical Information Systems for Land Resources Assessment, Oxford University Press, New York, 1986.

Burton, A. and Bathurst, J. C.: Physically based modelling of shallow landslide sediment yield at a catchment scale, Environmental Geology, 35, 89-99, 1998.

Campbell, R. H.: Soil slips, debris flows, and rainstorms in the Santa Monica Mountains and vicinity, southern California, US Geological Survey, Professional Paper 851, 1975.

Carrara, A.: Multivariate models for landslide hazard evaluation, Math. Geol., 15, 402-426, 1983.

Ceriani, M., Lauzi, S. and Padovan, N.: Rainfalls and landslides in the Alpine area of Lombardia Region. Central Alps Italy. Proc. Int. Symp. Interpraevent 1992, Bern, 2, 9-20, 1992.

Crosta, G.: Rainfall threshold regionalization: an aid for landslide susceptibility zonation. Environmental Geology, 35, (2/3), 131145, 1998.

Crosta, G. B. and Frattini, P.: Rainfall thresholds for triggering soil slips and debris flow, Proc. 2nd Plinius Conference on Mediterranean Storms, Siena, Italy, 16-18 October, in press, 2000.

Crosta, G. B. and Frattini, P.: Physically based distributed modelling for shallow landslide Hazard Zonation, Proc. 3rd EGS Plinius Conference, Baja Sardinia, Italy, 1-3 October, in press, 2001.

Crosta, G. B., Frattini, P., and Siena, L.: Shallow landslides triggered by rainfall: the 27-28 June 1997 event in Lecco Province (Lombardy, Italy), Geophysical Research Abstracts, 3, 8621, 2001.

Chow, V. T., Maidment, D. R., and Mays, L.W.: Applied Hydrology, McGraw-Hill, New York, 1988.

Chu, S. T.: Infiltration during an unsteady rain, Water Resources Research, 14 (3), 461-466, 1978.

Dunne, T., and Black, R. D.: An experimental investigation of runoff production in permeable soils, Water Resources Research, 6, 478-490, 1970.

Ellen, S. D.: Description and mechanics of soil slip/debris flows in the storm, in: Landslides, floods, and marine effects of the storm of January 3-5, 1982, in the San Francisco Bay Region, California, (Eds) Ellen S. D. and Wieczorek G. F., US Geol. Survey, 
Prof. Paper 1434, 64-111, 1988.

Ellen, S. D. and Fleming, R. W.: Mobilization of debris flows from soil slips, San Francisco bay region, California, in: Debris flows/avalanches: process, recognition, and mitigation, (Eds) Costa, J. E. and Wieczorek, G. F., Geological society of America Reviews in Engineering Geology, 7, 31-40, 1987.

Fredlund, D. C.: Slope stability analysis incorporating the effect of soil suction, in: Slope Stability, (Eds) Anderson, M. G. and Richards, K. S., Wiley, 1987.

Fredlund, D. C. and Xing, A.: Equations for the soil water characteristic curve, Canadian Geotechnical Journal, 31 (3), 521-532, 1994.

Green, W. H. and Ampt, G.: Studies of soil physics. Part 1. The flow of air and water through soils, J. Agricultural Soc., 4, 1-24, 1911.

Hammond, C., Hall, D., Miller, S., and Swetik, P.: Level I Stability Analysis (LISA) documentation for version 2.0. Gen. Tech. Rep. INT-285. For. Serv. US Dep of Agric., Ogden, Utah, 1992.

Held, E. and Joss, J.: The influence of the orography on precipitation seen by the Swiss radars. COST 75 Seminar on Advanced Radar Systems, Brussels, 20-23 September, 1994.

Hutchinson, M. F.: A new procedure for gridding elevation and stream line data with automatic removal of spurious pits, J. of Hydrology, 106, 211-232, 1989.

Humbert, M.: La Cartographie ZERMOS. Modalités d'établissement des cartes des zones exposées à des risques liés aux mouvements du sol et du sous-sol, BRGM Bull., Serie II, Sect. III, 1/2, 5-8, 1977.

Iverson, R. M.: Landslide triggering by rain infiltration, Water Resources Research, 36, 1897-1910, 2000.

Joss, J., Schadler, B., Galli, G., Cavalli, R., Boscacci, M., Held, E., Della Bruna, G., Kappenberger, G., Nespor, V., and Spiess, R.: Operational use of radar for precipitation measurement in Switzerland, Final Report of National Research Programme "Climate Changes and Natural Disasters" NRP31, vdf Hochschulverlag AG an der ETH Zürich, 1998.

Kienholz, H.: Maps of geomorphology and natural hazard of Grindelwald, Switzerland: scale 1:10.000, Arctic and Alpine Research, 10 (2), 169-84, 1978.

Mein, R. G. and Larson, C. L.: Modelling the infiltration component of the rainfall-runoff process, Bull. 43. St. Paul, Minn., Water Resources Research Centre, Univ. of Minnesota, 1973.

Montgomery, D. R. and Dietrich, W. E.: A Physically based model for the topographic control on shallow landsliding, Water Resources Research, 30, 83-92, 1994.

Morrissey, M. M, Wieczorek, G. F., and Morgan, B. A.: A comparative analysis of hazard models for predicting debris flows in Madison County, Virginia, US Geological Survey Open file report 01-67, 16, 2001.

Moser, M. and Hohensinn, F.: Geotechnical aspects of soil slips in alpine regions, Eng. Geol., 19, 185-211, 1983.

Neuman, S. P.: Wetting front pressure head in the infiltration model of Green and Ampt, Water Resources Research, 12, 564-566, 1976.

Pack, R. T., Tarboton, D. G., and Goodwin, C. N.: The Sinmap Approach to Terrain Stability Mapping. Proc. 8th Congress of the International Association of Engineering Geology, Vancouver, British Columbia, 1998.

Quinn, P. F., Beven, K. J., Chevallier, P., and Planchon, O.: The prediction of hillslope flow paths for distributed hydrological modelling using digital terrain models, Hydrological Processes, 9, 161-182, 1991.

Rawls, W. J. and Brakensiek, D. L.: Estimation of water retention and hydraulic properties, in: Unsaturated flow in Hydrologic Modelling: Theory and Practice, (Ed) Morel-Seytoux, H. J., Kluwer Academic, 1998.

Richards, L. A.: Capillary conduction of liquids through porous mediums, Physics, 1, 318-333, 1931.

Salvucci, G. D. and Entekhabi, D.: Explicit expressions for GreenAmpt (Delta function diffusivity) infiltration rate and cumulative storage, Water Resources Research, 30, 2661-2663, 1994.

Schönborn, G.: Alpine Tectonics and kinematic models of the Central Southern Alps, Società Cooperativa Tipografica, Padova, 1992.

Sidle, R. C. and Swanston, D. N.: Analysis of a small debris slide in coastal Alaska, Canadian Geotechnical Journal, 19, 167-174, 1982.

Soil Conservation Service, National Engineering Handbook, Sect. 4, Hydrology. US Dept. of Agriculture, Washington D. C., 1972.

Srivastava, P., Costello, T. A., and Edwards, D. R.: A direct, approximate solution to the modified Green-Ampt infiltration equation, Transactions of the American Society of Agricultural Engineers, 39 (4), 1411-1413, 1996.

Van Genuchten, M. Th.: A closed form equation for predicting the hydraulic conductivity of unsaturated soils, Soil Science Society of American Journal, 44, 892-898, 1980.

Wieczorek, G. F., Morgan, B. A., and Campbell, R. H.: Debris-Flow Hazards in the Blue Ridge of Central Virginia, Environmental and Engineering Geosciences, 6 (1), 3-23, 2000.

Wieczorek, G. F., McWreath, H. C., and Davenport, C.: Remote sensing for landslide Hazard Analysis, Proc. 3rd EGS Plinius Conference, Baja Sardinia, Italy, 1-3 October, in press, 2001.

Wu, W. and Sidle, R. C.: A distributed slope stability model for steep forested basins, Water Resources Research, 31, $2097-$ 2110, 1995.

Yin, K. L. and Yan, T. Z.: Statistical prediction model for slope instability of metamorphosed rocks, Proc. V Int. Symp. on Landslides, Lausanne, Switzerland, 2, 1269-1272, 1988. 